OPEN ACCESS

Edited by:

Juan Jose Munoz-Perez,

University of Cádiz, Spain

Reviewed by:

Jennifer M. Brown,

National Oceanography Centre,

United Kingdom

Yann Balouin,

Bureau de Recherches Géologiques et Minières, France

*Correspondence:

Curt Storlazzi

cstorlazzi@usgs.gov

Specialty section: This article was submitted to

Coastal Ocean Processes,

a section of the journal

Frontiers in Marine Science

Received: 11 October 2019

Accepted: 13 March 2020

Published: 31 March 2020

Citation:

Winter G, Storlazzi C, Vitousek S, van Dongeren A, McCall R, Hoeke $R$,

Skirving W, Marra J, Reyns J,

Aucan J, Widlansky M, Becker J,

Perry C, Masselink G, Lowe $R$,

Ford M, Pomeroy A, Mendez F,

Rueda A and Wandres M (2020)

Steps to Develop Early Warning

Systems and Future Scenarios of Storm Wave-Driven Flooding Along

Coral Reef-Lined Coasts.

Front. Mar. Sci. 7:199.

doi: 10.3389/fmars.2020.00199

\section{Steps to Develop Early Warning Systems and Future Scenarios of Storm Wave-Driven Flooding Along Coral Reef-Lined Coasts}

Gundula Winter ${ }^{1}$, Curt Storlazzi ${ }^{2 *}$, Sean Vitousek ${ }^{2}$, Ap van Dongeren ${ }^{1}$, Robert McCall', Ron Hoeke ${ }^{3}$, William Skirving ${ }^{4}$, John Marra ${ }^{5}$, Johan Reyns ${ }^{1}$, Jerome Aucan ${ }^{6}$, Matthew Widlansky ${ }^{7}$, Janet Becker ${ }^{8}$, Chris Perry ${ }^{9}$, Gerd Masselink ${ }^{10}$, Ryan Lowe ${ }^{11}$, Murray Ford ${ }^{12}$, Andrew Pomeroy ${ }^{11}$, Fernando Mendez ${ }^{13}$, Ana Rueda ${ }^{13}$ and Moritz Wandres ${ }^{14}$

1 Unit of Marine and Coastal Systems, Deltares, Delft, Netherlands, ${ }^{2}$ Pacific Coastal and Marine Science Center, U.S. Geological Survey, Santa Cruz, CA, United States, ${ }^{3}$ Sea Level, Waves and Coastal Extremes Group, Commonwealth Scientific and Industrial Research Organisation, Melbourne, VIC, Australia, ${ }^{4}$ NESDIS, Center for Satellite Applications and Research, National Oceanic and Atmospheric Administration, Cranbrook, QLD, Australia, ${ }^{5}$ NESDIS, National Centers for Environmental Information, National Oceanic and Atmospheric Administration, Honolulu, HI, United States, ${ }^{6}$ Laboratory for Studies in Geophysics and Spatial Oceanography, Research Institute for Development, Noumea, New Caledonia, ${ }^{7}$ International Pacific Research Center, University of Hawai' i, Honolulu, HI, United States, ${ }^{8}$ Department of Mechanical and Aerospace Engineering, University of California, San Diego, San Diego, CA, United States, ${ }^{9}$ Department of Geography, University of Exeter, Exeter, United Kingdom, ${ }^{10}$ School of Biological and Marine Sciences, University of Plymouth, Plymouth, United Kingdom, " UWA Oceans Institute and Oceans Graduate School, The University of Western Australia, Perth, WA, Australia, ${ }^{12}$ School of Environment, The University of Auckland, Auckland, New Zealand, ${ }^{13}$ Department of Sciences and Techniques in Water and Environment, University of Cantabria, Santander, Spain, ${ }^{14}$ Geoscience, Energy and Maritime Division, Pacific Community (SPC), Suva, Fiji

Tropical coral reef-lined coasts are exposed to storm wave-driven flooding. In the future, flood events during storms are expected to occur more frequently and to be more severe due to sea-level rise, changes in wind and weather patterns, and the deterioration of coral reefs. Hence, disaster managers and coastal planners are in urgent need of decision-support tools. In the short-term, these tools can be applied in Early Warning Systems (EWS) that can help to prepare for and respond to impending storm-driven flood events. In the long-term, future scenarios of flooding events enable coastal communities and managers to plan and implement adequate risk-reduction strategies. Modeling tools that are used in currently available coastal flood EWS and future scenarios have been developed for open-coast sandy shorelines, which have only limited applicability for coral reef-lined shorelines. The tools need to be able to predict local sea levels, offshore waves, as well as their nearshore transformation over the reefs, and translate this information to onshore flood levels. In addition, future scenarios require long-term projections of coral reef growth, reef composition, and shoreline change. To address these challenges, we have formed the UFORiC (Understanding Flooding of Reef-lined Coasts) working group that outlines its perspectives on data and model 
requirements to develop EWS for storms and scenarios specific to coral reef-lined coastlines. It reviews the state-of-the-art methods that can currently be incorporated in such systems and provides an outlook on future improvements as new data sources and enhanced methods become available.

Keywords: coral reef, coast, flooding, sea level, waves, Early Warning System, climate-change scenarios

\section{INTRODUCTION}

Tropical coral reef-lined coasts are becoming increasingly at risk of local and remotely generated wave-driven flooding. The frequency and severity of these flood events differ regionally depending on local variability and trends in the hydrodynamic forcing such as mean sea level, storm occurrence, and wave climate (e.g., Vitousek et al., 2017a; Reguero et al., 2019). While these challenges are universal for all types of coastlines, communities of reef-lined coasts are facing additional challenges. Firstly, coral reefs are living bio-geomorphic systems whose structure and function highly depend on their health. Globally, reef health is under threat from local stressors, ocean acidification, and global warming (Hoegh-Guldberg et al., 2017; Hughes et al., 2017). The deteriorating state of reefs reduces their natural coastal protection function (Sheppard et al., 2005; Ferrario et al., 2014; Beck et al., 2018) because reefs with reduced structure attenuate less waves (Harris et al., 2018) and because effective reef depth increases through a combination of sealevel rise, slowing rates of vertical reef accretion (Perry et al., 2018), and dredging of reefs for building material as practiced in some island nations. Secondly, when human dwellings and critical infrastructure are located within low-lying coastal plains or atoll rims (e.g., Kumar and Taylor, 2015; Owen et al., 2016), islands are highly vulnerable to flooding events (Beetham and Kench, 2018) with limited options for retreat to higher grounds. Reef-lined coasts can be exposed to highly energetic locally generated wind-sea when they are located within the area of influence of tropical cyclones but also to remotely generated ocean swell (Hoeke et al., 2013). For reef-lined islands exposed to tropical storms (particularly, those situated on a shallow continental shelf), flood levels are further aggravated by high storm-surge levels.

Recent events such as Typhoon Haiyan (Roeber and Bricker, 2015) and widespread flooding of islands due to remotely generated swell in the western Pacific (Hoeke et al., 2013) highlight the need to warn the public of impending coastal flooding events. Short-term forecasts (typically up to 7 days) produced by an Early Warning System (EWS) allow local authorities to issue timely warnings and to coordinate preparedness and evacuation measures, which ultimately reduces risk to lives and assets. Such systems have been implemented in sandy coast environments (e.g., Kleermaeker et al., 2012), but reef-lined coasts demand different modeling approaches due to: (1) the relatively larger importance of infragravity waves (see Bertin et al., 2018 for a recent review on infragravity waves), (2) increased setup over the reef due to its structure (Buckley et al., 2016), and not yet well understood (3) wave breaking on the forereef and (4) reef development, sediment production, and reef-to-shore transport, and (5) the development of the (sedimentary) coastline.

In the next decades, the frequency and severity of extreme sea-level events is predicted to increase, particularly along lowlatitude coastlines (Wahl et al., 2017; Vousdoukas et al., 2018). Extreme events may damage both natural and built infrastructure immediately, while less severe but frequent marine flooding may cause salt water contamination of the fresh water lenses, leaving them unusable for human consumption and agriculture. Without adaptation the lack of water and food security is anticipated to be a primary driver that renders many coral reef-lined coasts uninhabitable (Storlazzi et al., 2018). Where coastal adaptation is not feasible, communities will be forced to migrate landward or to relocate elsewhere, potentially causing significant cultural and societal impacts. Building resilience into natural, built, and socio-economic systems requires adequate time for planning and implementation. Understanding future changes in waves and extreme sea levels and resultant flood hazards are key to inform effective coastal adaptation in the long-term (several decades). Hazard scenarios need to provide projections of sea level rise and coral reef state that are long enough to detect trends amongst the annual and decadal variations that will dominate regional sea levels over the next two decades (Wahl et al., 2017).

The development of accurate EWS to forecast short-term coastal hazards and scenario modeling capabilities to project long-term impacts of climate change is critical to support local managers and planners with adequate decision support tools to reduce the current and emerging risk of coastal flooding. At present, numerous factors hinder the development of EWS and long-term modeling tools: Reef-lined coasts remain underrepresented in terms of in situ data collection and there is a lack of fundamental data on reef morphology, island topography, local sea level, and nearshore wave climate (particular under extreme conditions); and islands are often below the resolution of global models, with little to no higher-resolution regional models available in most of the world. Here, we outline approaches to construct these modeling tools with currently available methods and data and we provide an outlook on potential improvements to these tools as new data and methods become available and point out key research gaps to address.

\section{BACKGROUND: APPROACHES TO STORM-DRIVEN COASTAL FLOOD MODELING FOR REEF-LINED COASTS}

The processes to consider for coastal flooding in a short-term forecast (1-3) and a future scenario (1-5) include: (1) sea level 
(tidal and non-tidal residuals); (2) offshore wave conditions; (3) nearshore waves and wave-driven water levels; (4) reef accretion, sediment production and reef-to-shore transport; and (5) the development of sedimentary coasts (Figure 1).

\section{Modeling Requirements and Available Tools}

In the following, we first outline the steps required to build an EWS suited to predict flooding on short-time scales and then we describe the requirements to model projections of future flooding for different climate-change, socio-demographic and coastal management scenarios.

\section{EWS Methodology (Short-Term Predictions, on the Order of Days)}

Most of the individual components required to develop a simple prototype EWS for coastal flooding along reef-lined coasts are already available. An EWS needs to link four of the five modules illustrated in Figure 2 that forecast: (1) sea level (tidal and nontidal residuals); (2) offshore wave conditions; (3) nearshore waves and wave-driven water levels; (5) coastal flooding; and in more sophisticated models (4) event-driven sediment transport. We next outline the individual modules and the data requirements that are essential to build an EWS.

The local tidal levels for a prototype EWS can presently be predicted through harmonic analysis using tidal constituents derived from tide gauges. For remote locations without tide gauges, tidal water levels are extracted from global tide models that typically integrate satellite altimetry such as FES2014 (Carrere et al., 2015) or TPXO (Egbert and Erofeeva, 2002). More accurate sea-level forecasts need to incorporate sea-level anomalies due to ocean circulations, which are provided operationally on a global and regional scale by an increasing number of institutions (Tonani et al., 2015). Recent developments in the modeling of sea-level anomalies allow even seasonal outlooks (McIntosh et al., 2015) with better skill when results from multiple forecast models are combined (Widlansky et al., 2017). In the long term, technological advances in satellite technology, such as Sentinel-3 (ESA, 2019), ICESat-2 (NASA, $2019 \mathrm{~b}$ ) and the SWOT satellite mission that is to be launched in 2021 (NASA, 2019b), will eventually be able to provide sealevel observations at high spatial resolution and in real-time to be used for data assimilation in operational systems as, for example, currently employed in Lellouche et al. (2018).

Offshore wave heights can currently be provided by operational global wave models such as WaveWatch-III (WW3; Tolman, 2009). Local effects including wave refraction, diffraction, and locally generated wind-sea (e.g., due to tropical cyclones) can be accounted for through regionally downscaled models that make use of numerical techniques such as SWAN (Booij et al., 1999), analytical functions based on linear wave theory, or empirical methods. All downscaling techniques require accurate bathymetry and validation data. More so than in other environments, phasing and directional spectral information of the wave field are important because they influence wave generation in the infragravity (IG) and very low frequency (VLF) bands, which can excite resonance over reef platforms and cause flooding (Péquignet et al., 2009; Roeber and Bricker, 2015). The spectral information to accurately estimate IG and VLF motions may be available from satellites in the future when data from improved satellite altimeters (e.g., SWOT) can be combined with directional spectral data derived from Synthetic-Aperture Radar (SAR) satellite observations (Le Traon et al., 2015). This would improve wave observations currently limited to significant wave heights (e.g., from Sentinel-3).

The output of the offshore wave module is fed into the nearshore module to estimate extreme water levels at the shoreline, for example using the parameterization by Merrifield et al. (2014). As coastal flooding can also be related to wave run-up and overtopping rather than only mean water levels at the shoreline, an improved nearshore wave module would predict wave run-up levels from offshore wave data (e.g., from WW3), for example, using probabilistic or deterministic models such as BEWARE (Pearson et al., 2017) or HyCReWW (Rueda et al., 2019). These models of run-up are parameter-based and require most importantly characteristic reef dimensions such as reef width, depth, slope, and hydrodynamic roughness (reef complexity and/or coral cover) that can be extracted from satellite imagery or automated remote sensing algorithms (e.g., Dekker et al., 2011; Chirayath and Earle, 2016). In the long-term, increasing computational capacity will enable the use of dynamic process-based transect (1D), two-dimensional (2D-horizontal) or fully $3 \mathrm{D}$ models in the nearshore module that can also include event-driven sediment and coral rubble transport and resultant morphological updates (Vila-Concejo and Kench, 2017).

In the flood module, the water levels and wave run-up levels from the nearshore module will need to be translated into a meaningful site-specific measure of flooding. Local topographic surveys (e.g., LIDAR) are not available or not in a standardized elevation datum for most reef-island locations. Without these data, water and wave run-up levels can be referenced to the highest high-water level or other benchmark so that end-users can judge the severity of a flood event based on experience. This local knowledge can be systematically surveyed and used in combination with a hindcast of key past events to forecast the likely extent and inundation height of a future flooding event. Globally available topographic data sets such as SRTM (NASA, 2019a) and derived products that improve vertical accuracy (e.g., Kulp and Strauss, 2018) still have insufficient spatial resolution (3 arcseconds) to resolve pathways for flood waters (e.g., channels and small-scale depressions). In the future, improved remote sensing techniques from such satellites as ICESat- 2 will provide higher resolution and more accurate topographic and nearshore bathymetric data for detailed flood mapping.

\section{Scenario Methodology (Long-Term Projections, on the Order of Decades)}

In order to evaluate different future scenarios of waves and sea-level extremes, modeling capabilities need to be developed to make projections of expected flood levels for the coming decades under these scenarios. These should be key inputs for sustainable coastal adaptation planning that reduce expected sealevel rise impacts. The projection modeling suite will require information from the four modules essential for an EWS (sea 


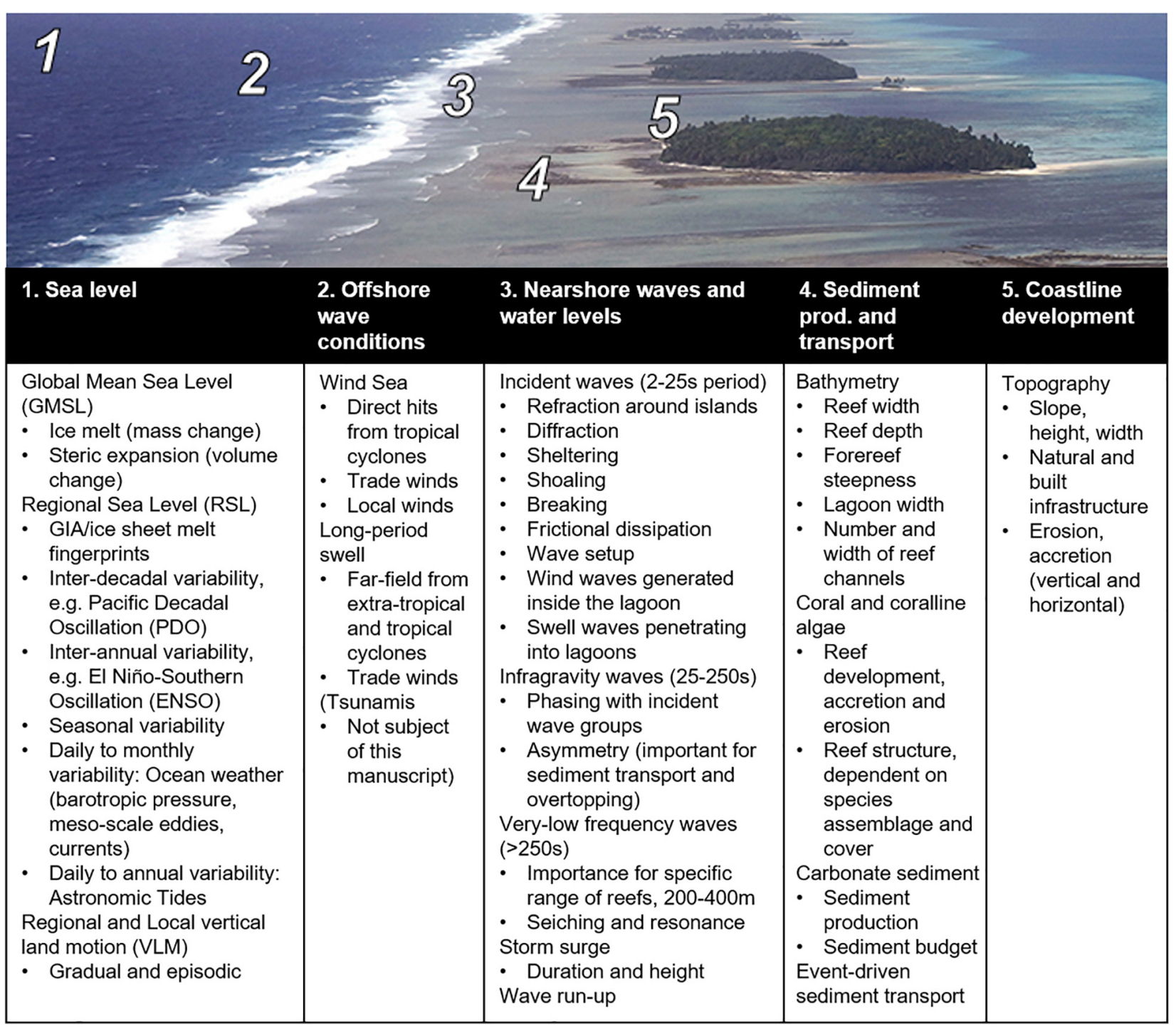

FIGURE 1 | Processes relevant to wave-driven coastal flooding, from offshore to onshore: 1. Sea level. 2. Offshore wave conditions. 3. Nearshore waves and wave-driven water levels. 4. Reef development, sediment production, and reef-to-shore transport. 5. Coastline development. The table lists the key drivers of flooding for each of component.

level, wave climate, nearshore wave transformation, and water level over future reef structures). In addition to these data, future projections need to account for the state of reef health, carbonate sediment production and lagged transport to the coastline (" 4 " in Figure 2). Coral reefs exhibit natural variation but ocean warming (Hughes et al., 2017) and local stressors such as landbased sources of pollution, over fishing and disease (e.g., Ban et al., 2014) change reef morphology due to mortality, species selection, and modified growth rates. Thus, projections will need to evaluate different scenarios of climate change (related to ocean warming and rainfall) and socio-economic developments to account for differences in species assemblage, coral cover (and physical roughness), carbonate sediment production, and vertical reef accretion rates that combined with sea level projections determine future reef depths and consequently the coastal protection function of reefs (e.g., Ferrario et al., 2014; Quataert et al., 2015).

Global and regionally downscaled sea-level projections have already been developed (e.g., Kopp et al., 2017), but need to be further downscaled to account for local trends where regional sea-level trends are incoherent as, for example, in the Caribbean (Torres and Tsimplis, 2013). Improved downscaling techniques must include both gradual and episodic vertical land motions, ice-melt fingerprints, and other physical processes (e.g., Kopp et al., 2014). Likewise, global and regional wave-climate projections are already available (e.g., Hemer et al., 2013), but also need to be statistically or dynamically downscaled to a local level. The offshore water level and wave climate can be used in parametric models to transform waves to the nearshore and to calculate water level and wave run-up at the shoreline. 


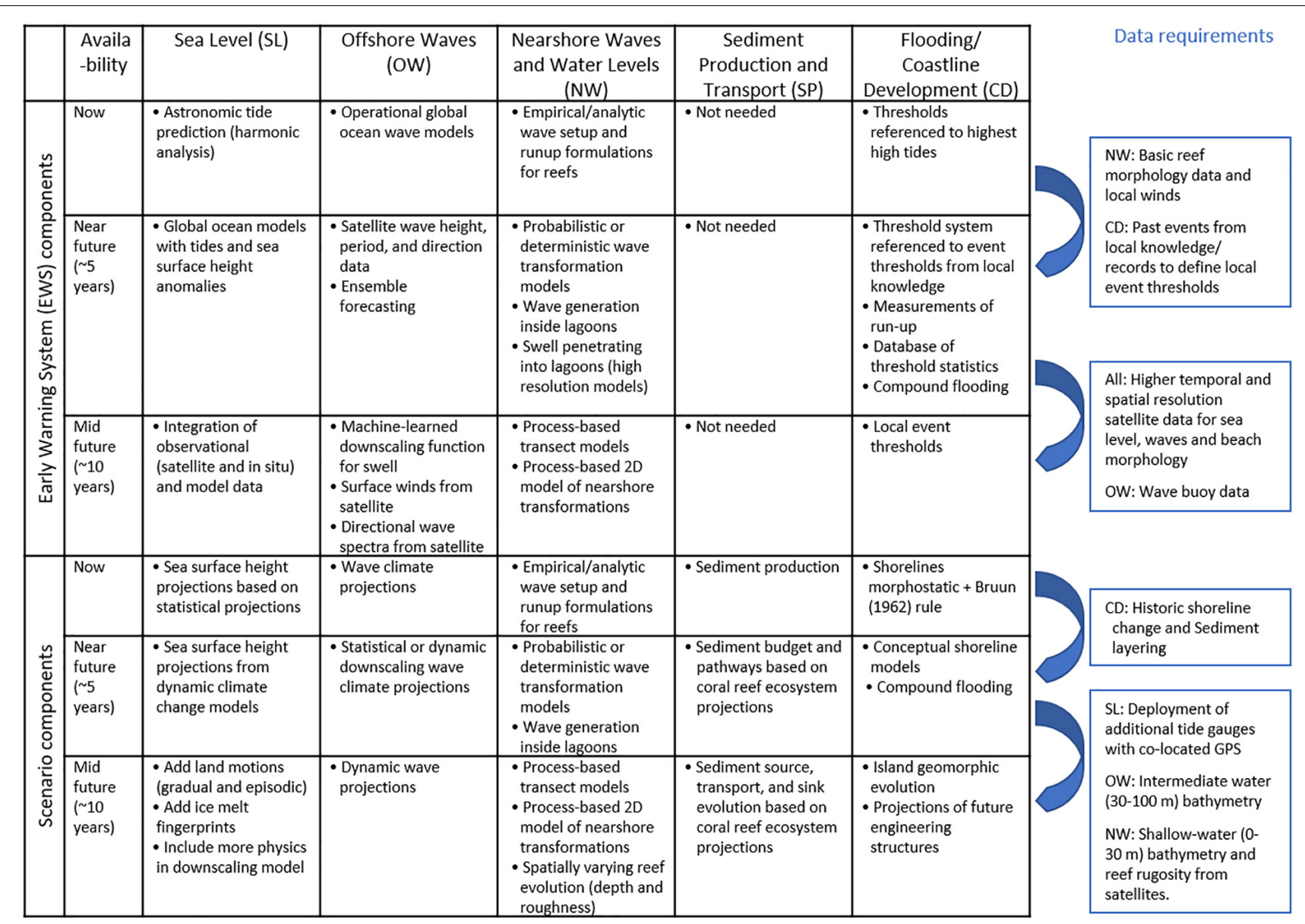

FIGURE 2 | Modules required to develop (top) a coastal flood Early Warning System (EWS) and (bottom) a scenario modeling tool, which can be implemented immediately (now), in the near-term, and in the long term. Blue boxes on the right describe key data gaps that need to be filled to develop the next generation of EWS or scenario modeling tool.

These parametric models can produce a large set of scenarios to address uncertainties in sea-level and wave-climate projections and to identify key scenarios that can be evaluated with dynamic two-dimensional models. More sophisticated nearshore models need to include local wave growth and hence require wind fields downscaled from global projections. Future scenarios also need to account for changes and uncertainties in coral-reef morphology and species assemblages, which determine wave dynamics on reefs (Baldock et al., 2014) and ultimately nearshore water levels and wave run-up (Quataert et al., 2015).

Simple projections of future flooding often apply a "morphostatic" approach that neglects future shoreline adjustments in response to altered reef states. Application of the simple Bruun (1962) rule to predict beach profile changes in response to sea-level rise are hardly valid because the concept of a "closure depth" developed for open sandy coastlines is not relevant for reef-lined coastlines (Cowell and Kench, 2001). More sophisticated predictive models that account for sediment production and sinks specific to reef-lined coasts will require data on historic shorelines, as well as sediment coring and dating to understand trends in sediment production and accumulation through time (Perry et al., 2018), especially over the past few decades where the impact of recent sea-level rise in many portions of the tropical Pacific Ocean (Becker et al., 2012) can be used to better project future changes. Such models also need to include anthropogenic interventions such as engineering structures that impact upon future shoreline development. Recently, long-term shoreline evolution models have been developed for open-coast sandy beaches with simple configurations (e.g., Vitousek et al., 2017b; Robinet et al., 2018; Antolínez et al., 2019), yet, few studies (e.g., de Alegria-Arzaburu et al., 2013) exist for coral reef-lined beaches, especially at longer time scales. While existing studies of wave-driven evolution of perched beaches might represent a suitable proxy for reef-lined coasts either the dimensions of the submerged barriers are not consistent with coral reefs (e.g., González et al., 1999), the potential effect of infragravity waves has not been considered and/or they provide only conceptual models (e.g., Gallop et al., 2012).

Finally, for such a projection modeling suite to be of value to coastal planners and decision-makers, a selection of relevant scenarios of climate change, sea-level rise, and (local) 
socio-economic development is essential to assess different management options.

Overall, future advances in EWS and scenario modeling capabilities may mainly follow from (1) enhanced computational capacity resulting in the use of models that incorporate more physical processes, (2) better parameterization of small-scale processes in these models, (3) improved topographic-bathymetric data, and (4) the integration of more observational data, which may be sourced through remote sensing, low-cost monitoring or citizen science. Detailed data requirements for these future advances are:

- Better spatial coverage with tide gauges, particularly with co-located GPS receivers that identify local land subsidence or uplift at the shoreline;

- Better coverage with wave buoys, especially in the southern hemisphere;

- Nearshore bathymetry between the 100 and $10 \mathrm{~m}$ isobaths for downscaling of wave data;

- Direct observations of wave run-up to improve our understanding of the physical processes relevant to run-up onshore of coral reefs and to calibrate and validate models, particularly during extreme events;

- High (approximately $2 \mathrm{~m}$ horizontal) spatial resolution bathymetry and topography between $10 \mathrm{~m}$ depths and $10 \mathrm{~m}$ land elevations; as well as habitat maps for wave modeling and forecasting of absolute flood levels and extents; and

- Historical analysis of flood events and impacts to validate EWS.

To develop more accurate forecasts tools, research needs to address the following knowledge gaps:

- Improved downscaling techniques for offshore waves, possibly through development of machine-learning algorithms, to downscale global wave projections (not unique to reef-lined coasts);

- Better estimates of vertical reef growth rates under different ecological states of the reef to project future water depth on the reef with sea-level rise, which is a governing parameter for wave dissipation over the reef and wave run-up at the shoreline;

- Quantification of carbonate sediment production and transport, which is still little researched but important for projections of shoreline configurations.

- Physically based roughness parameterization from coral cover and reef benthic complexity in dynamic models because current models simply scale friction formulations developed for sandy beds and do not account for energy dissipation within the coral canopy;

- Better understanding of wave breaking over reefs, which has been little researched due to the difficult instrumentation of the surf zone on reefs but which controls wave setup, VLF and IG motions, residual sea-swell wave heights onshore of the reef, and wave run-up;

- Better understanding of the importance of infragravity, very-low frequency waves, and seiching to flooding along reef-lined coasts, which has been documented for selected extreme events (e.g., Péquignet et al., 2009; Roeber and Bricker, 2015) to inform the selection of an appropriate nearshore wave model;

- Better understanding of the importance of two-dimensional wave processes that can drive alongshore variability in wave run-up in coral reef-lined coastlines to evaluate the need for a fully two-dimensional nearshore model.

\section{WAY FORWARD}

To address the urgent need for coastal flooding EWS and future scenario modeling tools, the UFORiC (Understanding Flooding Of Reef-lined Coasts) working group has been established. This group has committed to meet regularly to advance and update work plans. The ultimate goal of this working group is to develop the tools and research that aid disaster risk management and climate change adaptation in coral reef-lined coasts. A priority of UFORiC is to establish links with national meteorological services and emergency managers, as well as other stakeholders such as development banks and insurance companies. The development of EWS and scenario modeling tools requires a multi-disciplinary research effort, and thus the UFORiC working group includes leading coastal engineers, physical oceanographers, geologists, geographers, ecologists, remotesensing specialists, and climate-change scientists. The effective implementation of these tools would be aided by training on data acquisition, management and interpretation (e.g., Cambers and Diamond, 2010).

\section{AUTHOR CONTRIBUTIONS}

CS, AD, RM, RH, WS, and JM contributed to the conception and design of the study. GW, CS, and SV wrote the first draft of the manuscript. All authors contributed to manuscript revision, read, and approved the submitted version.

\section{FUNDING}

This research is a product of the UFORiC working group, which was supported by the National Oceanic and Atmospheric Administration (NOAA), the U.S. Geological Survey (USGS), Deltares, and the Commonwealth Scientific and Industrial Research Organisation (CSIRO), and under the auspices of the Group on Earth Observations (GEO) Blue Planet initiative. The scientific results and conclusions, as well as any views or opinions expressed herein, are those of the author(s) and do not necessarily reflect the views of NOAA or the Department of Commerce. Use of trademark names does not imply US Government endorsement of products. 


\section{REFERENCES}

Antolínez, J. A. A., Méndez, F. J., Anderson, D., Ruggiero, P., and Kaminsky, G. M. (2019). Predicting climate-driven coastlines with a simple and efficient multiscale model. J. Geophys. Res. Earth Surf. 124, 1596-1624. doi: 10.1029/ 2018jf004790

Baldock, T. E., Golshani, A., Callaghan, D. P., Saunders, M. I., and Mumby, P. J. (2014). Impact of sea-level rise and coral mortality on the wave dynamics and wave forces on barrier reefs. Mar. Pollut. Bull. 83, 155-164. doi: 10.1016/j. marpolbul.2014.03.058

Ban, S. S., Graham, N. A. J., and Connolly, S. R. (2014). Evidence for multiple stressor interactions and effects on coral reefs. Glob. Chang. Biol. 20, 681-697. doi: $10.1111 /$ gcb.12453

Beck, M. W., Losada, I. J., Menéndez, P., Reguero, B. G., Díaz-Simal, P., and Fernández, F. (2018). The global flood protection savings provided by coral reefs. Nat. Commun. 9:2186. doi: 10.1038/s41467-018-04568-z

Becker, M., Meyssignac, B., Letetrel, C., Llovel, W., Cazenave, A., and Delcroix, T. (2012). Sea level variations at tropical Pacific islands since 1950. Glob. Planet. Change 8, 85-98. doi: 10.1016/j.gloplacha.2011.09.004

Beetham, E., and Kench, P. S. (2018). Predicting wave overtopping thresholds on coral reef-island shorelines with future sea-level rise. Nat. Commun. 9:3997. doi: 10.1038/s41467-018-06550-1

Bertin, X., Bakker, A. D., Dongeren, A. V., Coco, G., André, G., Ardhuin, F., et al. (2018). Infragravity waves: from driving mechanisms to impacts. Earth Sci. Rev. 177, 774-799. doi: 10.1016/j.earscirev.2018.01.002

Booij, N., Ris, R., and Holthuijsen, L. H. (1999). A third-generation wave model for coastal regions: 1 . Model description and validation. J. Geophys. Res. Oceans 104, 7649-7666. doi: 10.1029/98JC02622

Bruun, P. (1962). Sea-level rise as a cause of shore erosion. J. Waterways Harb. Div. 88, 117-132.

Buckley, M. L., Lowe, R. J., Hansen, J. E., and Van Dongeren, A. R. (2016). Wave setup over a fringing reef with large bottom roughness. J. Phys. Oceanogr. 46, 2317-2333. doi: 10.1175/JPO-D-15-0148.1

Cambers, G., and Diamond, P. (2010). Sandwatch: Adapting to Climate Change and Educating for Sustainable Development. Paris: UNESCO.

Carrere, L., Lyard, F., Cancet, M., and Guillot, A. (2015). "FES 2014, a new tidal model on the global ocean with enhanced accuracy in shallow seas and in the Arctic region," in Proceedings EGU General Assembly Conference Abstracts (Vienna: EGU General Assembly).

Chirayath, V., and Earle, S. A. (2016). Drones that see through waves-preliminary results from airborne fluid lensing for centimetre-scale aquatic conservation. Aquat. Conserv. 26, 237-250. doi: 10.1002/aqc.2654

Cowell, P. J., and Kench, P. S. (2001). The morphological response of atoll islands to sea-level rise. Part 1: modifications to the shoreface translation model. J. Coast. Res. Spec. Issue 34, 633-644.

de Alegria-Arzaburu, A. R., Mariño-Tapia, I., Enriquez, C., Silva, R., and GonzálezLeija, M. (2013). The role of fringing coral reefs on beach morphodynamics. Geomorphology 198, 69-83. doi: 10.1016/j.geomorph.2013.05.013

Dekker, A. G., Phinn, S. R., Anstee, J., Bissett, P., Brando, V. E., Casey, B., et al. (2011). Intercomparison of shallow water bathymetry, hydrooptics, and benthos mapping techniques in Australian and Caribbean coastal environments. Limnol. Oceanogr. Methods 9, 396-425. doi: 10.4319/lom.2011. 9.396

ESA (2019). European Space Agency: Sentinel-3 Mission Overview. Available online at: https://sentinel.esa.int/web/sentinel/missions/sentinel-3 (accessed March 15, 2019).

Egbert, G. D., and Erofeeva, S. Y. (2002). Efficient inverse modeling of Barotropic ocean tides. J. Atmos. Ocean. Technol. 19, 183-204. doi: 10.1175/15200426(2002)019<0183:eimobo>2.0.co;2

Ferrario, F., Beck, M. W., Storlazzi, C. D., Micheli, F., Shepard, C. C., and Airoldi, L. (2014). The effectiveness of coral reefs for coastal hazard risk reduction and adaptation. Nat. Commun. 5:3794. doi: 10.1038/ncomms4794

Gallop, S. L., Bosserelle, C., Eliot, I., and Pattiaratchi, C. B. (2012). The influence of limestone reefs on storm erosion and recovery of a perched beach. Cont. Shelf Res. 47, 16-27. doi: 10.1016/j.csr.2012.08.001

González, M., Medina, R., and Losada, M. A. (1999). Equilibrium beach profile model for perched beaches. Coast. Eng. 36, 343-357. doi: 10.1016/S03783839(99)00018-6
Harris, D. L., Rovere, A., Casella, E., Power, H., Canavesio, R., Collin, A., et al. (2018). Coral reef structural complexity provides important coastal protection from waves under rising sea levels. Sci. Adv. 4:eaao4350. doi: 10.1126/sciadv. aao4350

Hemer, M. A., Fan, Y., Mori, N., Semedo, A., and Wang, X. L. (2013). Projected changes in wave climate from a multi-model ensemble. Nat. Clim. Chang. 3, 471-476. doi: 10.1038/nclimate1791

Hoegh-Guldberg, O., Poloczanska, E. S., Skirving, W., and Dove, S. (2017). Coral reef ecosystems under climate change and ocean acidification. Front. Mar. Sci. 4:158. doi: 10.3389/fmars.2017.00158

Hoeke, R. K., McInnes, K. L., Kruger, J. C., McNaught, R. J., Hunter, J. R., and Smithers, S. G. (2013). Widespread inundation of Pacific islands triggered by distant-source wind-waves. Glob. Planet. Change 108, 128-138. doi: 10.1016/j. gloplacha.2013.06.006

Hughes, T. P., Barnes, M. L., Bellwood, D. R., Cinner, J. E., Cumming, G. S., Jackson, J. B. C., et al. (2017). Coral reefs in the Anthropocene. Nature 546, 82-90. doi: 10.1038/nature22901

Kleermaeker, S., Verlaan, M., Kroos, J., and Zijl, F. (2012). "A new coastal flood forecasting system for the Netherlands," in Proceedings of the Hydro12 - Taking Care of the Sea (Heeg: Hydrographic Society Benelux).

Kopp, R. E., DeConto, R. M., Bader, D. A., Hay, C. C., Horton, R. M., Kulp, S., et al. (2017). Evolving understanding of Antarctic ice-sheet physics and ambiguity in probabilistic sea-level projections. Earths Future 5, 1217-1233. doi: 10.1002/2017ef000663

Kopp, R. E., Horton, R. M., Little, C. M., Mitrovica, J. X., Oppenheimer, M., Rasmussen, D. J., et al. (2014). Probabilistic 21st and 22nd century sea-level projections at a global network of tide-gauge sites. Earths Future 2, 383-406. doi: 10.1002/2014EF000239

Kulp, S. A., and Strauss, B. H. (2018). CoastalDEM: A global coastal digital elevation model improved from SRTM using a neural network. Remote Sens. Environ. 206, 231-239. doi: 10.1016/j.rse.2017.12.026

Kumar, L., and Taylor, S. (2015). Exposure of coastal built assets in the South Pacific to climate risks. Nat. Clim. Chang. 5:992. doi: 10.1038/nclimate2702

Le Traon, P. Y., Antoine, D., Bentamy, A., Bonekamp, H., Breivik, L. A., Chapron, B., et al. (2015). Use of satellite observations for operational oceanography: recent achievements and future prospects. J. Oper. Oceanogr. 8, s12-s27. doi: 10.1080/1755876X.2015.1022050

Lellouche, J. M., Greiner, E., Le Galloudec, O., Garric, G., Regnier, C., Drevillon, M., et al. (2018). Recent updates to the Copernicus Marine Service global ocean monitoring and forecasting real-time $1 / 12^{\circ}$ highresolution system. Ocean Sci. 14, 1093-1126. doi: 10.5194/os-14-10932018

McIntosh, P. C., Church, J. A., Miles, E. R., Ridgway, K., and Spillman, C. M. (2015). Seasonal coastal sea level prediction using a dynamical model. Geophys. Res. Lett. 42, 6747-6753. doi: 10.1002/2015GL0 65091

Merrifield, M. A., Becker, J. M., Ford, M., and Yao, Y. (2014). Observations and estimates of wave-driven water level extremes at the Marshall Islands. Geophys. Res. Lett. 41, 7245-7253. doi: 10.1002/2014GL061005

NASA (2019a). Jet Propulsion Laboratory: Shuttle Radar Topography Mission. Available online at: https://www2.jpl.nasa.gov/srtm/ (accessed March 15, 2019).

NASA (2019b). Jet Propulsion Laboratory: Surface Water and Ocean Topography Mission. Available online at: https://swot.jpl.nasa.gov/ (accessed March 15, 2019).

Owen, S. D., Kench, P. S., and Ford, M. (2016). Improving understanding of the spatial dimensions of biophysical change in atoll island countries and implications for island communities: a Marshall Islands' case study. Appl. Geogr. 72, 55-64. doi: 10.1016/j.apgeog.2016.05.004

Pearson, S. G., Storlazzi, C. D., van Dongeren, A. R., Tissier, M. F. S., and Reniers, A. J. H. M. (2017). A bayesian-based system to assess wave-driven flooding hazards on coral reef-lined coasts. J. Geophys. Res. Oceans 122, 10099-10117. doi: 10.1002/2017JC013204

Péquignet, A. C. N., Becker, J. M., Merrifield, M. A., and Aucan, J. (2009). Forcing of resonant modes on a fringing reef during tropical storm Man-Yi. Geophys. Res. Lett. 36:L03607. doi: 10.1029/2008GL036259

Perry, C. T., Alvarez-Filip, L., Graham, N. A. J., Mumby, P. J., Wilson, S. K., Kench, P. S., et al. (2018). Loss of coral reef growth capacity to track future increases in sea level. Nature 558, 396-400. doi: 10.1038/s41586-018-0194-z 
Quataert, E., Storlazzi, C., van Rooijen, A., Cheriton, O., and van Dongeren, A. C. G. L. (2015). The influence of coral reefs and climate change on wavedriven flooding of tropical coastlines. Geophys. Res. Lett. 42, 6407-6415. doi: 10.1002/2015gl064861

Reguero, B. G., Losada, I. J., and Méndez, F. J. (2019). A recent increase in global wave power as a consequence of oceanic warming. Nat. Commun. 10:205. doi: 10.1038/s41467-018-08066-0

Robinet, A., Idier, D., Castelle, B., and Marieu, V. (2018). A reduced-complexity shoreline change model combining longshore and cross-shore processes: the LX-Shore model. Environ. Model. Softw. 109, 1-16. doi: 10.1016/j.envsoft.2018. 08.010

Roeber, V., and Bricker, J. D. (2015). Destructive tsunami-like wave generated by surf beat over a coral reef during Typhoon Haiyan. Nat. Commun. 6:7854. doi: $10.1038 /$ ncomms 8854

Rueda, A., Cagigal, L., Pearson, S. G., Antolinez, J. A. A., Storlazzi, C. D., van Dongeren, A., et al. (2019). HyCReWW: a hybrid coral reef waves and water level metamodel. Comput. Geosci. 127, 85-90. doi: 10.1016/j.cageo.2019.03.004

Sheppard, C., Dixon, D. J., Gourlay, M., Sheppard, A., and Payet, R. (2005). Coral mortality increases wave energy reaching shores protected by reef flats: examples from the Seychelles. Estuar. Coast. Shelf Sci. 64, 223-234. doi: 10.1016/ j.ecss.2005.02.016

Storlazzi, C. D., Gingerich, S. B., van Dongeren, A., Cheriton, O. M., Swarzenski, P. W., Quataert, E., et al. (2018). Most atolls will be uninhabitable by the mid21 st century because of sea-level rise exacerbating wave-driven flooding. Sci. Adv. 4:eaap9741. doi: 10.1126/sciadv.aap9741

Tolman, H. L. (2009). User manual and system documentation of WAVEWATCH III TM version 3.14. Silver Spring, MD: NOAA.

Tonani, M., Balmaseda, M., Bertino, L., Blockley, E., Brassington, G., Davidson, F., et al. (2015). Status and future of global and regional ocean prediction systems. J. Oper. Oceanogr. 8, s201-s220. doi: 10.1080/1755876X.2015.1049892

Torres, R. R., and Tsimplis, M. N. (2013). Sea-level trends and interannual variability in the Caribbean Sea. J. Geophys. Res. Oceans 118, 2934-2947. doi: 10.1002/jgrc.20229
Vila-Concejo, A., and Kench, P. (2017). Storms in coral reefs. Coast. Storms Process. Impacts 127-149. doi: 10.1002/9781118937099.ch7

Vitousek, S., Barnard, P. L., Fletcher, C. H., Frazer, N., Erikson, L., and Storlazzi, C. D. (2017a). Doubling of coastal flooding frequency within decades due to sea-level rise. Sci. Rep. 7:1399. doi: 10.1038/s41598-017-01362-7

Vitousek, S., Barnard, P. L., Limber, P., Erikson, L., and Cole, B. (2017b). A model integrating longshore and cross-shore processes for predicting long-term shoreline response to climate change. J. Geophys. Res. Earth Surf. 122, 782-806. doi: 10.1002/2016JF004065

Vousdoukas, M. I., Mentaschi, L., Voukouvalas, E., Verlaan, M., Jevrejeva, S., Jackson, L. P., et al. (2018). Global probabilistic projections of extreme sea levels show intensification of coastal flood hazard. Nat. Commun. 9:2360. doi: 10.1038/s41467-018-04692-w

Wahl, T., Haigh, I. D., Nicholls, R. J., Arns, A., Dangendorf, S., Hinkel, J., et al. (2017). Understanding extreme sea levels for broad-scale coastal impact and adaptation analysis. Nat. Commun. 8:16075. doi: 10.1038/ncomms16075

Widlansky, M. J., Marra, J. J., Chowdhury, M. R., Stephens, S. A., Miles, E. R., Fauchereau, N., et al. (2017). Multimodel ensemble sea level forecasts for tropical pacific islands. J. Appl. Meteorol. Climatol. 56, 849-862. doi: 10.1175/ JAMC-D-16-0284.1

Conflict of Interest: The authors declare that the research was conducted in the absence of any commercial or financial relationships that could be construed as a potential conflict of interest.

Copyright (c) 2020 Winter, Storlazzi, Vitousek, van Dongeren, McCall, Hoeke, Skirving, Marra, Reyns, Aucan, Widlansky, Becker, Perry, Masselink, Lowe, Ford, Pomeroy, Mendez, Rueda and Wandres. This is an open-access article distributed under the terms of the Creative Commons Attribution License (CC BY). The use distribution or reproduction in other forums is permitted, provided the original author(s) and the copyright owner(s) are credited and that the original publication in this journal is cited, in accordance with accepted academic practice. No use, distribution or reproduction is permitted which does not comply with these terms. 